\title{
Exploitation of arctic sea ice by epibenthic copepods
}

\author{
E. H. Grainger \\ Arctic Biological Station, 555 St. Pierre Blvd., Ste. Anne de Bellevue, Quebec, Canada H9X 3R4
}

\begin{abstract}
The harpacticoid Tisbe furcata and the cyclopoid Cyclopina schneideri are the dominant ice meiofaunal copepods in Frobisher Bay, Canadian Arctic. Maximum concentrations of $T$ furcata in the lower $5 \mathrm{~cm}$ of the ice exceed $250000 \mathrm{~m}^{-3}$, of C. schneideri $125000 \mathrm{~m}^{-3}$, and by late winter the 2 species are $10^{3}$ to $10^{4}$ more concentrated in the ice than in the water column below. In contrast, the 2 species appear during the ice-free season to be relatively minor components of the nearshore system, living mainly in the epibenthic phytal habitat. Their feeding style is well suited to phytal living, as it is to ice dwelling, but they are less well equipped to feed in the water column. Ascending in mid-winter from relatively poor epibenthic feeding conditions, they encounter the rich food supply developing at that time in the lower levels of the ice, where algal concentations are at least $10^{3}$ times higher than in the water column below. In this environment the ice copepods flourish. As the ice melts, the surviving ice copepods disperse, some apparently returning to their near-botton habitat.
\end{abstract}

\section{INTRODUCTION}

The harpacticoid copepod Tisbe furcata (Baird) and the cyclopoid copepod Cyclopina schneideri (Scott) have long been considered as minor components of the arctic marine fauna. In the North American Arctic, both species have been encountered occasionally, usually in small numbers on or close to the sea bottom or less often higher in the water column (Shih et al. 1971).

In contrast to the usually small numbers encountered elsewhere, large numbers of both species have been shown to occupy the lower few centimetres of annual sea ice in the Arctic (Cross 1982, Kern \& Carey 1983, Horner \& Murphy 1985, Grainger \& Mohammed 1986, Cross \& Martin 1987, Grainger 1988). Tisbe furcata is also reported from the Antarctic ice (Gruzov et al. 1967 , Andriashev 1968).

As part of a study of the ice fauna carried out between 1980 and 1985 in Frobisher Bay (Canadian eastern Arctic), the 2 species were shown to be the numerically dominant copepods in the ice, accounting for more than $95 \%$ of all copepods collected between February and late May. Both were found as minor constituents, at no time comprising more than $4 \%$ of copepods, in the plankton during the year. Both moved into the lower levels of the sea ice during the winter and there developed especially dense populations, more concentrated by more than 2 orders of magnitude than any found outside the ice. With the disappearance of the annual ice cover in early summer, both apparently descended into deeper water where they remained for the most part until the following ice season.

The objective of this paper is to show how, in the presence of a suitable sea ice cover, these 2 comparatively minor elements of the open-water demersal or shallow-water planktonic fauna of the Arctic expand their habitat, enter the lower levels of the sea ice, and in the presence of the abundant food supply developed there become dominant members of the temporary winter-spring sea ice fauna.

\section{METHODS}

The study area is located at the head of Frobisher Bay, on the southeast coast of Baffin Island. The main collecting site, about $40 \mathrm{~m}$ deep, is ice-covered from November until July, during which time the ice reaches a maximum thickness of close to $2 \mathrm{~m}$. The sea ice melts from late May or early June into July, then clears, leaving open water which persists until November (Grainger 1975). The algal bloom is already 
present in the lower levels of the ice in February and remains until it is lost by melting into the water column below in early summer. The ice fauna develops in the same levels of the ice and also remains until the ice begins to melt. The sea bottom in the study area supports a dense growth of Laminaria spp. and other macrophytes.

Using an ice corer of $7.6 \mathrm{~cm}$ diameter, 24 cores taken from the lower $5 \mathrm{~cm}$ of the ice in February, March, April and May included Tisbe furcata and Cyclopina schneideri as part of the ice biota. Samples at the icewater interface and in the ca $5 \mathrm{~cm}$ of water just beneath the ice were obtained from an under-ice sampler which scraped the lower surface of the ice and from a submersible pump.

The under-ice sampler (Grainger \& Hsiao 1982) includes a collector box with a rectangular opening $15.2 \mathrm{~cm}$ wide and $3.0 \mathrm{~cm}$ deep. The collector is moved along the lower surface of the ice with the opening forward. It is controlled from the top of the ice by a vertical component which penetrates the ice hole and a horizontal arm which guides the collector along a circular path with an adjustable radius (183 cm maximum). A single sweep of one full circle scrapes an ice surface of $1.75 \mathrm{~m}^{2}$ and samples $0.05 \mathrm{~m}^{3}$ of water.

The submersible pump, a commercial 'Little Giant', was used to make 21 collections just below the surface of the ice and about $25 \mathrm{~cm}$ above the sea bottom (see below). Pumping rates were measured in each field situation and varied from 3.9 to $9.31 \mathrm{~min}^{-1}$. Pumping times ranged from 2 to $15 \mathrm{~min}$. All ice-related samples were taken during daylight hours.

In the water column, 28 vertical plankton tows using nets of $30 \mathrm{~cm}$ ring ciameter and $73 \mu \mathrm{m}$ mesh made from about $1 \mathrm{~m}$ above the sea bottom to the surface yielded one or both of these species. The nets collected only during the ascent. No meter was used, but the relatively small quantity of plankton filtered during single hauls not exceeding $50 \mathrm{~m}$ in length precluded clogging of the meshes. Catching efficiency was therefore close to $100 \%$

Sixteen pump samples were collected $25 \mathrm{~cm}$ above the sea bottom at about $40 \mathrm{~m}$ depth in May and in August, using the submersible pump. All were taken amongst Laminaria and other macrophytes which grew densely in the area where the ice studies were conducted.

The benthic meiofauna in the area was examined with the aid of 10 core samples taken to a depth of $12 \mathrm{~cm}$ into the substrate. These were collected in summer and winter. In addition, a large number of Petersen type grab hauls taken on the site through all seasons over a period of 10 years were examined for meiobenthic copepods.

\section{RESULTS}

Numbers of Tisbe furcata in the sea ice of upper Frobisher Bay increased from $5987 \mathrm{~m}^{-3}$ in February to $250988 \mathrm{~m}^{-3}$ in May (Fig. 1). The opposite trend was evident in the water column below the ice, where numbers fell from $55 \mathrm{~m}^{-3}$ in February to near 0 in May. The species persisted in small concentrations in the water column through June and July.

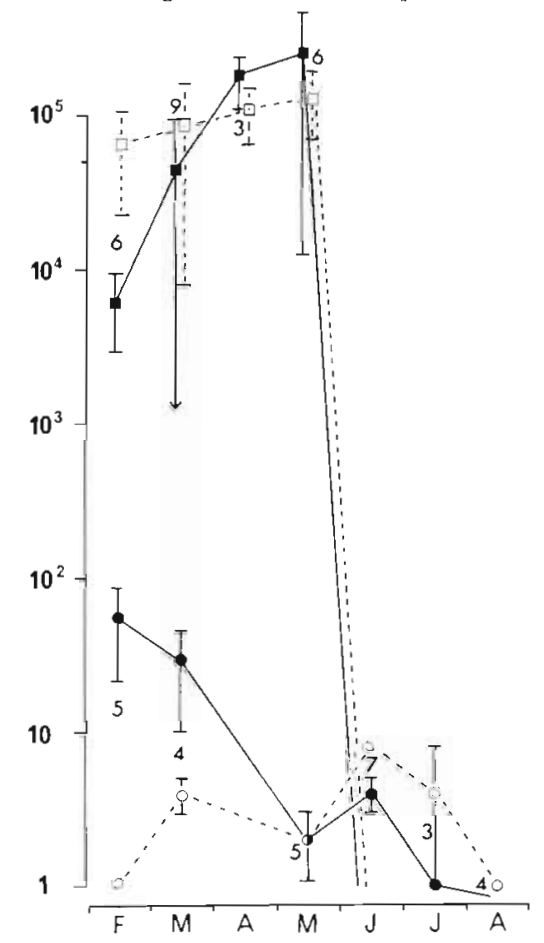

Fig. 1. Numbers $\left(\mathrm{m}^{-3}\right)$ of Tisbe furcata in the ice ( - ) and in the water column $(\bullet)$, and of Cyclopina schnejderi in the ice $(-)$ and in the water column () between February and August in Frobisher Bay, Canada. Vertical lines represent \pm 1 standard deviation. Numbers of collections used to determine each mean are shown in the figure

Adults of both sexes dominated in the ice in February (Fig. 2). Egg-bearing females were present in March, and there was evidence of a new generation of early copepodid stages in the ice, and only in the ice, in May. During the same period, the small numbers found at the ice-water interface were mainly older copepodids. but the slightly larger numbers occurring in the water column below the ice were younger individuals which gradually diminished over winter.

As the ice melted in June only small numbers of animals of all kinds were collected in the water column Early summer collections from near the bottom are lacking, but material taken in August shows that a substantial population of Tisbe furcata of around $4500 \mathrm{~m}^{-3}$, consisting mainly of young copepodid stages 

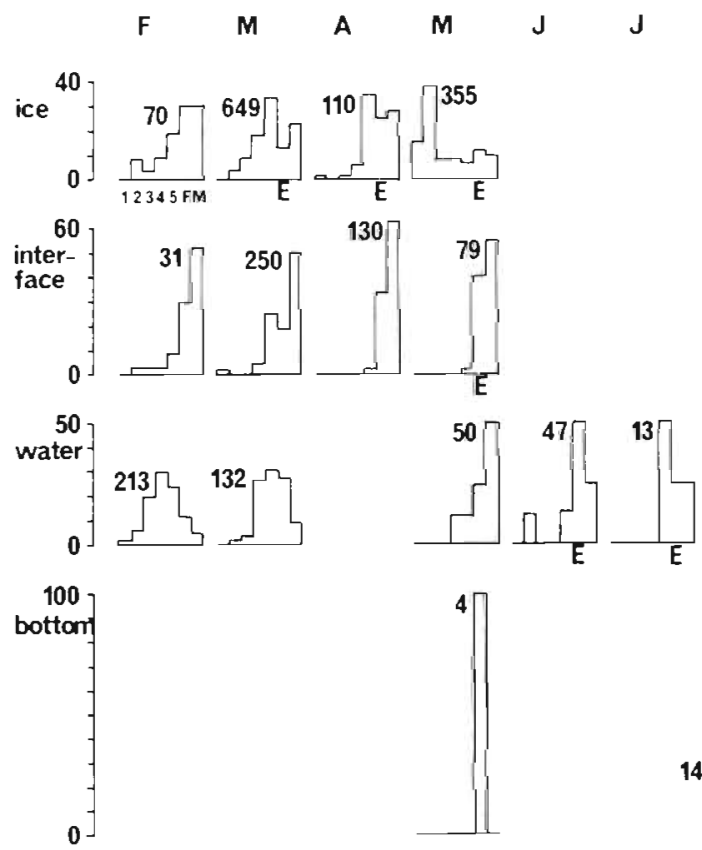

A

Fig. 2. Tisbe furcata. Relative frequency of developmental stages ( $\mathrm{C}-1$ to $\mathrm{C}-5$, adult females and males) in the ice, at the ice-water interface, in the water column and just off the sea bottom between February and August in Frobisher Bay. $E$ : females bearing eggs. Numbers of specimens used to construct each histogram are shown in the figure

and egg-bearing females, existed just above the bottom, amongst thickly growing macrophytes, at that time.

During summer, vertical net hauls made from about $1 \mathrm{~m}$ above the bottom to the surface took only small numbers of mostly adult Tisbe furcata (Fig. 2). During the same period, coring and grab sampling of the bottom collected a variety of harpacticoids, but at no time did they include $T$. furcata, which has not yet been found as a component of the benthic infauna in Frobisher Bay but only as a demersal copepod close to, but not on or in, the substrate.

Cyclopina schneideri was confined largely to the ice during this study. Unlike Tisbe furcata, C. schneideri showed a fairly steady concentration of copepodids in the ice, varying only from about 64700 to $128400 \mathrm{~m}^{-3}$ (Fig. 1). No clear trend was discernible in the water column below the ice, where numbers were consistently low.

Copepodid stages 1 and 2 dominated in the ice in February and March, C-3 in April and C-4 in May (Fig. 3). Stage C-5 increased in number between April and May and both adult males and females with eggs appeared in May. There were only small differences between stage frequencies at the ice-water interface and in the ice above, except for the presence at the interface of females in February, March and April, not found at the time in the ice. Numbers were extremely
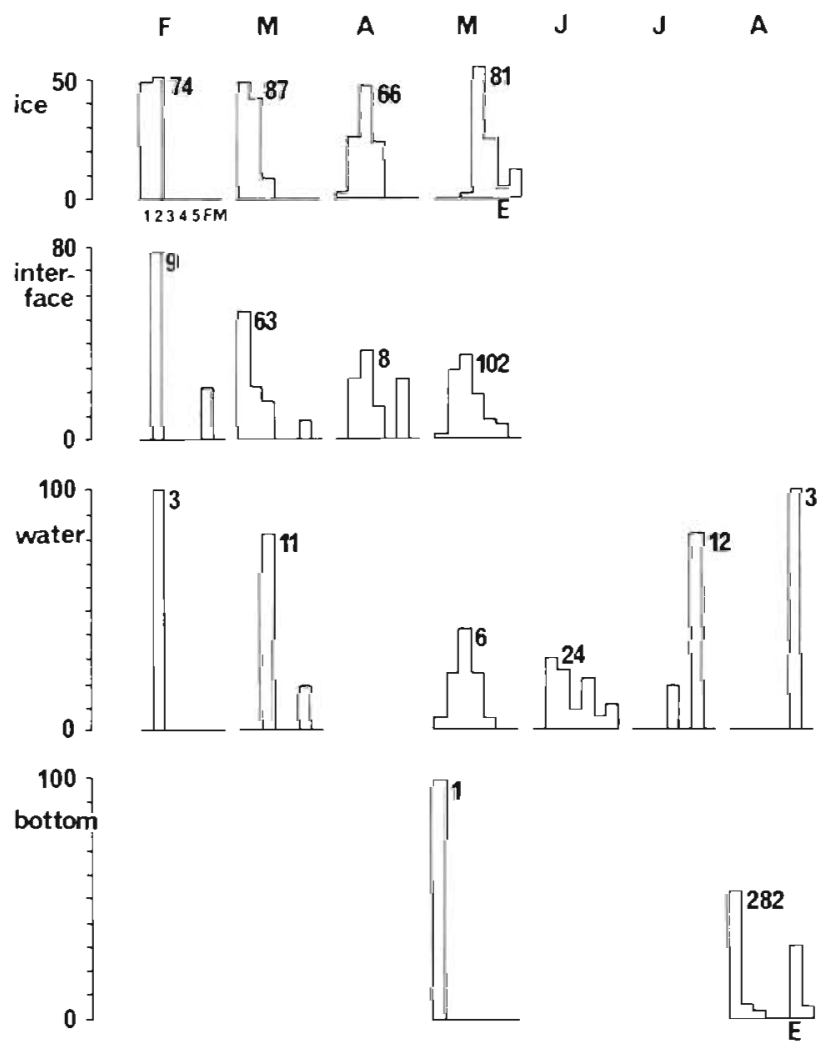

Fig. 3. Cyclopina schneiderei. Relative frequency of developmental stages ( $\mathrm{C}-1$ to $\mathrm{C}-5$, adult females and males) in the ice, at the ice-water interface, in the water column and just off the sea bottom between February and August in Frobisher Bay. $E$ : females bearing eggs. Numbers of specimens used to construct each histogram are shown in the figure

small in the water column. They were small in May just above the bottom, but grew to more than $1800 \mathrm{~m}^{-3}$ by August, by which time $\mathrm{C}-1$ and adult females predominated.

A sequence of development from $\mathrm{C}$-1 to egg-bearing adults took place in the ice between February and May. A new generation then appeared in the water column as the ice disappeared. Evidence of this was seen in the water column in June, and of continued breeding just above the bottom in August.

\section{DISCUSSION}

Tisbe furcata was described by Lang (1948) as being mainly benthic. Although shown as long as 70 yr ago to occur planktonically in arctic waters (Willey 1920), it was included only relatively recently (Hauspie \& Polk 1973) among 'some harpacticoid species, until now considered benthic [which] became pelagic at times'. These authors concluded that the copepodids could swim, and that the nauplii could not. 
Tisbe furcata was included by Hicks (1980) among the phytal species, and found associated with a number of macrophytes. Several authors since have emphasized the phytal affinities of T. furcata (Hicks 1986. Walters \& Bell 1986, Bell et al. 1987. Hicks 1988).

The ability of both Tisbe furcata and Cyclopina schneideri, as well as other copepods, to undergo vertical migrations has been shown (Alldredge \& King 1980, Walters \& Bell 1986, Bell et al. 1988, Walters 1988). Food was shown to be a stimulus to movement by Decho (1986), who observed meiobenthic copepods moving upward to feed on diatoms in the water column. According to Hicks (1988), the great majority of meiobenthic copepods occurring in the water column are truly phytal species.

Suspension feeding is generally little practised among most of the harpacticoids and, with a few exceptions, the cyclopoids. Mouth parts in Tisbe and Cyclopina spp. are suited to grasping and holding prey rather than to straining out small organisms. T. furcata, along with the other harpacticoids which live in the ice, has been shown by Hicks \& Coull (1983) to feed from surfaces and to be a food crusher fitted with prehensile appendages to grasp its prey. It is not well adapted, therefore, to feeding in the water column, but it is especially equipped to remove food from surfaces such as those found in the various cryptic places of the phytal, and in the tight spaces of the lower surface of the sea ice.

A plant cell concentration of 2 to 3 orders of magnitude higher in the ice than in the water column below it makes the lower few centimetres of the ice an attractive source of nourishment for herbivores able to gain access to it and feed within it (Grainger \& Hsiao 1990). These abilities exist in both Tisbe furcata and Cyclopina schneideri. Ice algae of the genera Nitzschia, Navicula and Chlamydomonas have each been found in more than half the $T$ furcata shown to have fed in the ice in Frobisher Bay (Grainger \& Hsiao 1990). Species of the same 3 genera dominated the food of Cyclopina spp. in the same study, and they were among the most abundant food taxa living in the ice.

Tisbe furcata and Cyclopind schneideri in their winter movement to the ice entered a rich feeding habitat at a time when algal production in the ice was probably substantially greater than on the sea bottom or in the water column (Matheke \& Horner 1974, Horner \& Schrader 1982). Ice populations remained high as long as the ice algae continued abundant, that is until the decline of ice algae early in June (Fig. 4). During this time, phytoplankton numbers at $10 \mathrm{~m}$ and near the bottom grew, as did the rate of sedimentation to the sea bottom. Despite phytoplankton growth early in the open-water season (July), $T$. furcata and $C$. schneideri did not increase in numbers in the water

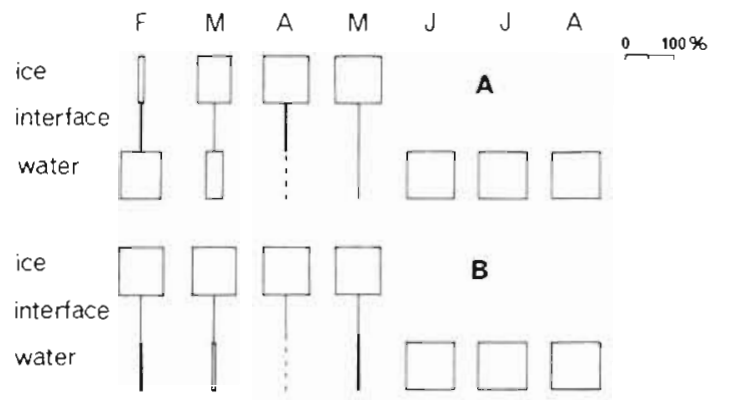

Fig. 4. Tisbe furcata and Cyclopina schneideri. Relative numbers in the ice, at the ice-water interface and in the water column between February and August in Frobisher Bay

column (thus differing from the major calanoid copepods of the water column, which began their summer population growth at that time). Instead, their numbers declined in the water column, as they apparently descended to near the bottom. There they appear to have reached fairly large concentrations during the period when organic sediments were falling to the bottom at their maximum rate for the year (Fig. 4).

These 2 ice-dwelling copepods show different strategies in their exploitation of the ice habitat. Tisbe furcata appeared to enter the ice over a prolonged period, lasting from February until at least April, during which time the ratio of water dwellers to ice occupants gradually shifted (Fig.5). The ice-occupancy phase ended with the production of a new generation. Cyclopina schneideri consisted of only young copepodids in the ice in early winter. There was comparatively little migration from the water below during the rest of the winter, in the course of which development in the ice appeared to reach maturity. Different stages of development, and hence different size groups of the 2 taxa (both of which are approximately the same size in comparable stages), were predominant in the ice at any one time. Thus, although they have closely similar diets, the size range of food particles may have been partitioned by the taxa when both occurred together in the ice.

The period of copepod occupancy of the ice began as long as 5 mo before the spring-summer phytoplankton bloom in Frobisher Bay. Access to a food-rich habitat this long before phytoplankton becomes abundant in the water column represents a significant 'head start' for the seasonal growth cycle of the copepods in the ice. While water-dwelling holoplanktonic copepods are still undergoing winter decline in numbers and planktonic food is falling to its lowest concentration of the year, copepods in the ice are moving rapidly towards their maximum annual population levels. Both ice species 


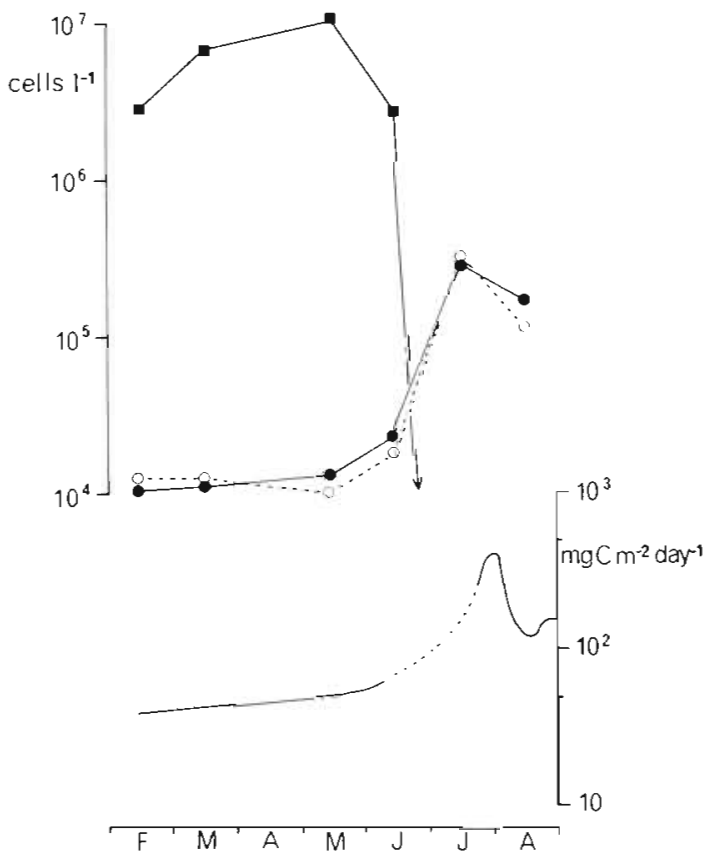

Fig. 5. Counts of ice algae (-) and of phytoplankton at $10 \mathrm{~m}(\bullet)$ and 1 to $2 \mathrm{~m}$ above the bottom (o) as cells $\mathrm{l}^{-1}$, and sedimentation rates as $\mathrm{mg} \mathrm{m}^{-2} \mathrm{~d}^{-1}$ between February and August in Frobisher Bay. From data in Grainger \& Hsiao (1982), Hsiao

\& Pinkewycz (1983), and Atkinson \& Wacasey (1987)

are able to expand significantly their habitat, their numbers and their ecological importance by exploiting the highly favourable seasonal environment provided by the ice.

Acknowledgements. I thank A. A. Mohammed for species identifications, a number of colleagues, especially J. E. Lovrity, for field collections, and Jon Percy for critical comments on the manuscript.

\section{LITERATURE CITED}

Alldredge, A. L., King, J. M. (1980). Effects of moonlight on the vertical migration patterns of demersal zooplankton. J. exp. mar Biol. Ecol. 44: 133-156

Andriashev, A. P. (1968). The problem of the life community associated with the antarctic fast ice. In: Currie, R. I. (ed.) Proc. Symposium Antarctic Oceanogr Scott Polar Res. Inst., Cambridge, p. 147-157

Atkinson, E. G., Wacasey, J. W. (1987). Sedimentation in arctic Canada: particulate organic carbon flux to a shallow marine benthic community in Frobisher Bay. Polar Biol. 8: 3-7

Bell, S. S., Hicks, G. R. F., Walters, K. (1988). Active swimming in meiobenthic copepods of seagrass beds: geographic comparisons of abundances and reproductive characteristics. Mar. Biol. 98: 351-358

Bell, S. S., Walters, K., Hall, M. O. (1987). Habitat utilization by harpacticoid copepods: a morphometric approach. Mar Ecol. Prog. Ser. 35: 59-64
Cross, W. E. (1982). Under-ice biota at the Pond Inlet ice edge and in adjacent fast ice areas during spring. Arctic 35: 13-27

Cross, W. E., Martin, C. M. (1987). Effects of oil and chemically treated oil on nearshore under-ice meiofauna studied in situ. Arctic 40, Suppl. 1 258-265

Decho, A. W. (1986). Water-cover influences on diatom ingestron rates by meiobenthic copepods. Mar Ecol. Prog. Ser 33: $139-146$

Grainger, E. H. (1975). A marine ecology study in Frobisher Bay, arctıc Canada. In: Cameron, T W M., Billingsley, L. W. (eds.) Energy flow - its biological dimensions. Canadian Committee IBP. Royal Society of Canada, Ottawa, p. 261-266

Grainger, E. H. (1988). The influence of a river plume on the sea-ice meiofauna in south-eastern Hudson Bay. Estuar coast. Shelf Sci. 27: 131-141

Grainger, E. H., Hsiao, S. I. C. (1982). A study of the ice biota of Frobisher Bay, Baffin Island 1979-1981 Can. Ms. Rep. Fish. Aquat. Sci. 1647

Grainger, E. H., Hsiao, S. I. C. (1990). Trophic relationships of the sea ice meiofauna in Frobisher Bay, arctic Canada. Polar Biol. 10: 283-292

Grainger, E. H., Mohammed, A. A. (1986). Copepods in arctic sea ice. In: Schriever, G., Schminke, H. K., Shih, C.-t. (eds.) Proc. Second Int. Conf. Copepoda. Syllogeus 58, Nat. Mus. Canada, Ottawa, p. 303-310

Gruzov, Y N., Propp. M. V., Pushkin, A. F. (1967). Biological associations of coastal areas of the Davis Sea (based on the observations of divers). Sov. Antarct. Exped. Inf. Bull. Issue 6, no. 6: 523-533

Hauspie, R., Polk, P. (1973). Swimming behavior patterns in certain benthic harpacticoids (Copepoda). Crustaceana 25: $95-103$

Hicks, G. R. F. (1980). Structure of harpacticoid copepod assemblages and the influence of habitat complexity and turbidity. J. exp. mar Biol. Ecol. 44: 157-192

Hicks, G. R. F. (1986). Distribution and behaviour of meiofaunal copepods inside and outside seagrass beds. Mar. Ecol. Prog. Ser. 31 159-170

Hicks, G. R. F. (1988). Evolutionary implications of swimming behaviour in meiobenthic copepods. Hydrobiologia $167 /$ 168: $497-504$

Hick.s, G. R. F., Coull, B. C. (1983). The ecology of marine meiobenthic harpacticoid copepods. Oceanogr mar Biol. A. Rev. 21. 67-175

Horner, R. Murphy, D. (1985). Species composition and abundance of zooplankton in the nearshore Beaufort Sea in winter-spring. Arctic 38: 201-209

Horner, R., Schrader, G. C. (1982). Relative contributions of ice algae, phytoplankton, and benthic microalgae to primary production in nearshore regions of the Beaufort Sea. Arctic 35: 485-503

Hsiao, S. I. C., Pinkewycz, N. (1983). Phytoplankton data from Frobisher Bay, 1979-1981. Can. Data Rep. Fish. Aquat. Sci. 419

Kern, J. C., Carey, A. C. Jr (1983). The faunal assemblage inhabiting seasonal sea ice in the nearshore Arctic Ocean with emphasis on copepods. Mar. Ecol. Prog. Ser. 10: 159-167

Lang, K. (1948). Monographie der Harpacticiden. (2 vols). H. Ohlssons Boktryckeri, Lund

Matheke, G. E. M., Horner, R. (1974). Primary productivity of the benthic microalgae in the Chukchi Sea near Barrow, Alaska. J. Fish. Res. Bd Can. 31: 1779-1786

Shih, C.-t., Figueira, A. J. G., Grainger, E. H. (1971). A synopsis of Canadian marine zooplankton. Fish. Res. Bd Can. Bull. 176 
Walters, K. (1988). Diel vertical migration of sediment-associated meiofauna in subtropical sand and seagrass habitats. J. exp. mar Biol Ecol. 117: 169-186

Walters, K., Bell, S. S. (1986). Diel patterns of active vertical

This article was submitted to the editor migration in seagrass meiofauna. Mar. Ecol. Prog. Ser. 34 95-103

Willey, A. (1920). Marine Copepoda. Rep. Can. Arct. Exped. 1913-1918, 7, Crustacea, K

Manuscript first received: September 25, 1990

Revised version accepted: August 28, 1991 